Ракушев М. Ю., д-р техн. наук, ст. наук. співроб. ${ }^{1}$

Зуйко В. В., канд. військ. наук, доцент ${ }^{1}$

Зотов С. В. ${ }^{1}$

Янчевський С. Л., канд. техн. наук²

1 - Інститут забезпечення військ (сил) та інформаційних технологій Національного університету оборони України імені Івана Черняховського, Київ;

2 - Національний центр управління та випробувань космічних засобів Державного космічного агентства України, Київ

\title{
Аналіз галузі дистанційного зондування Землі високої просторової розрізненості для вирішення завдань у сфері безпеки і оборони
}

Резюме. У статті проведено аналіз галузі дистанційного зондування Землі з космосу високої просторової розрізненості та наведені основні тенденції в зазначеній галузі. Показано, що основними споживачами матеріалів дистанційного зондування Землі $є$ урядові та силові відомства, частка яких складає приблизно $60 \%$. Проведено огляд можливостей установи Державного космічного агентства України - Національного центру управління та випробувань космічних засобів щодо отримання матеріалів космічного знімання високої просторової розрізненості.

Ключові слова: дистанційне зондування Землі, матеріали космічного спостереження високої просторової розрізненості; отримання матеріалів космічного знімання; Державне космічне агентство України.

Постановка проблеми. На теперішній час збройна агресія проти України i порушення ऑiі територіальної цілісності (окупація Російською Федерацією Автономної Республіки Крим та військова агресія Російської Федерації в окремих районах Донецької і Луганської областей), нарощування військової потужності Російської Федерації в безпосередній близькості до державного кордону України $\epsilon$ суттєвою загрозою у сфері національної безпеки i оборони. У зв'язку з цим, відновлення територіальної цілісності України та цілісності демократичних інститутів на всій iii території, реінтеграція тимчасово окупованих територій після їх звільнення $\epsilon$ стратегічним завданням політики національної безпеки України.

До основних цілей у сфері воєнної політики України відноситься іiі участь у реалізації спільної політики безпеки і оборони $\mathrm{CC}$, а також удосконалення системи забезпечення воєнної безпеки, яка б гарантувала надійний захист держави від зовнішніх i внутрішніх загроз, гідне сприйняття України на міжнародному рівні та відповідала критеріям членства України в СС і HATO.

Досвід, набутий унаслідок проведення останніх операцій НАТО яскраво свідчить, наскільки Альянс залежить від наявних космічних технологій, які надаються країнами та організаціями (зокрема, міжнародними компаніями), які мають відповідні космічні системи. Зважаючи на це, командна ланка, штаби та сили НАТО постійно вдосконалюють спроможності щодо кращої координації з використання космічних систем у сфері безпеки та оборони, а також, для відповідного забезпечення військових операцій.

3 огляду на необхідність нарощування спроможностей України у сфері безпеки i оборони та для подальшої реалізації спільної політики безпеки i оборони та членства України в НАТО, актуальним є використання даних космічних систем спостереження в інтересах національної безпеки та оборони.

Поряд 3 цим, за умови відсутності національної космічної системи спостереження, залишається єдиний можливий варіант реалізації космічних спроможностей у сфері безпеки та оборони, це - використання ресурсу іноземних (комерційних) систем. За для цього, в основних національних законодавчих i нормативно-правових актах щодо сфери космічної діяльності [1-4] зазначено на розкриття питання використання можливостей космічних систем дистанційного зондування Землі (ДЗ3) високої просторової розрізненості, які належать іноземним операторам для вирішення завдань у сфері національної безпеки і оборони.

Отже, метою статті $\epsilon$ проведення огляду світового ринку послуг дистанційного 
зондування Землі, компаній дистриб'юторів зазначених послуг представлених в Україні, а також можливостей Національного центру управління та випробувань космічних засобів щодо отримання матеріалів космічного знімання високої просторової розрізненості для вирішення завдань у сфері національної безпеки і оборони.

Викладення основного матеріалу. Спочатку космічне спостереження 3'явилось як військова технологія, але на сьогодні воно вже широко увійшло у комерційну (цивільну) сферу, де отримало назву - дистанційне зондування Землі (ДЗ3). До того ж, комерційні системи Д3З високої просторової розрізненості, майже в усіх країнах $\epsilon$ системами подвійного призначення, тобто, системами, які використовуються у воєнній i цивільній сферах.

Нині значний прогрес щодо розповсюдження інформаційних технологій, зростання потужностей мереж і комп'ютерів зробили використання даних Д3З доступним майже для будь-якого користувача - обробка космічних знімків стала доволі простою процедурою, у тому числі через наявність великої кількості спеціалізованих "хмарних" сервісів. Крім того, знайшли широке розповсюдження технологіï Big Data, які застосовуються до обробки масивів супутникових знімків, що дає змогу отримувати інформацію про довгострокові комплексні зв'язки (динаміка погодних умов, стан грунту, врожаїв, інфраструктури, господарської діяльності людини). Це робить технології Д3З ще більш затребуваними.

Отже, світовий ринок галузі ДЗ3 на теперішній час перебуває у стадії сталого зростання від поточних $\$ 4,2$ млрд до $\$ 8,5$ млрд (рис. 1) [5-7].

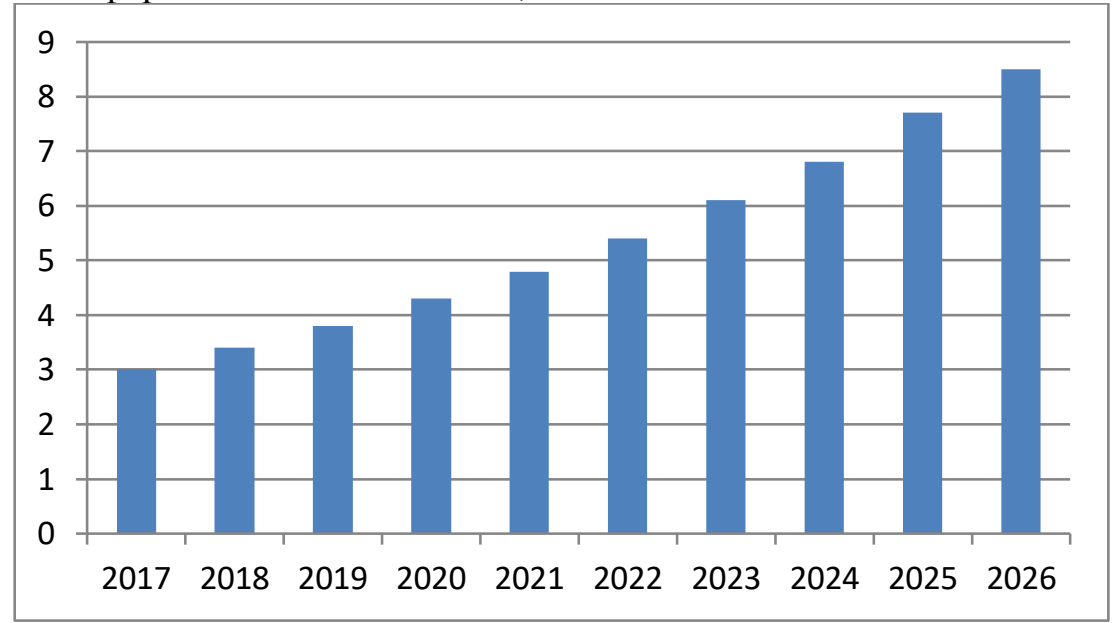

Рис. 1. Прогноз ринку послуг ДЗ3 у млрд дол. США

3 погляду на технологічні аспекти, можна виділити декілька трендів у галузі Д33:

1. Зменшення маси та розмірів використовуваних космічних апаратів (КА) (обумовлено покращенням апаратної бази, що дає змогу відмовитися від використання КА важкого класу), що дає змогу зменшити затрати на запуск.;

2. Збільшення кількості КА ДЗ3 дає змогу значно підвищити оперативність отримання знімків заданої ділянки, збільшити інформаційну продуктивність космічної системи (вимірюється загальною відзнятою площею) та використовувати більш інформативні стереознімки;

3. Удосконалення апаратної бази забезпечує більшу доступність радіолокаційних знімків i забезпечує впровадження технологій для проведення мульти- та гіперспектрального знімання оптико-електронними системами.
На сьогодні, за чисельністю супутникового угруповання Д3З провідні позиції займають США, Китай і ЄС. Дані за країнами та типами КА наведено у табл. 1, де OЕC - оптико-електронне спостереження, РЛС - радіолокаційне спостереження [8-13].

3 погляду на комерційні аспекти розвитку ринку Д33 можна виділити такі тренди:

1. Обсяг світового ринку матеріалів Д33 постійно зростає. Основними споживачами матеріалів Д33 є урядові та силові відомства. Ïх частка у загальному обсязі закупівель поступово зменшується, але залишається значною i нині складає близько $60 \%$. Для порівняння у 2012 році зазначена частка була $65 \%$.

2. Незважаючи на значну кількість комерційних КА та їх країн власників (табл. 1), основна частина доходів від продажу космічних знімків залишається під контролем 
двох основних компаній операторів: Digital Globe (США) - KA WorldView-1/2/3, GeoEye-1 та Air Bus (CC) - KA Pleades-1A/B та Spot-6/7. Хоча на ринку активно пропонують свої послуги: SI Imaging Services (Пд. Корея) - КА Kompsat-3/3A; Image Sat International N.V.
(Ізраїль) - KA Eros B та China Great Wall Industry Corporation (Китай) - KA SuperView-1 (01/02/03/04). Основні технічні характеристики зазначених КА ДЗ3 оптикоелектронного спостереження високої просторової розрізненості наведені в табл. 2.

Таблиця 1

Склад орбітального угруповання Д33 на вересень 2019

\begin{tabular}{|c|c|c|c|c|c|c|c|}
\hline \multirow{2}{*}{ № } & \multirow{2}{*}{ Країна } & \multicolumn{2}{|c|}{ Військові / Комерційні } & \multirow{2}{*}{ № } & \multirow{2}{*}{ Країна } & \multicolumn{2}{|c|}{ Військові / Комерційні } \\
\hline & & OEC & РЛС & & & OEC & РЛС \\
\hline 1 & США & $6 / 24$ & $7 / 2$ & 11 & Туреччина & $2 /-$ & - \\
\hline 2 & KHP & $23 / 30$ & $6 / 3$ & 12 & Республіка Корея & -13 & $-/ 1$ \\
\hline 3 & РФ & $4 / 9$ & $2 /-$ & 13 & EKA & -16 & $-/ 2$ \\
\hline 4 & Японія & $4 / 5$ & $5 / 2$ & 14 & Алжир & -13 & - \\
\hline 5 & Франція & $3 / 4$ & - & 15 & Білорусь & $-/ 1$ & - \\
\hline 6 & $\Phi P H$ & -15 & $5 / 2$ & 16 & Велика Британія & -15 & 1 \\
\hline 7 & Ізраїль & $4 / 1$ & $2 / 1$ & 17 & Венесуела & $-/ 2$ & - \\
\hline 8 & Італія & $1 / 1$ & -14 & 18 & Єгипет & $-/ 1$ & - \\
\hline 9 & Канада & - & -14 & 19 & Іран & $-/ 1$ & - \\
\hline 10 & Індія & $1 / 12$ & $1 / 2$ & 20 & Іспанія & -12 & - \\
\hline 11 & Туреччина & $2 /-$ & - & 21 & Казахстан & -13 & - \\
\hline & & & $\mathrm{EC}$ & $22 ;$ & РЛС - 28/24 & & \\
\hline
\end{tabular}

Таблиця 2

Технічні характеристики космічних апаратів Д33 оптико-електронного спостереження високої просторової розрізненості на місцевості

\begin{tabular}{|c|c|c|c|c|c|c|}
\hline № & $\begin{array}{c}\text { Космічний } \\
\text { апарат }\end{array}$ & $\begin{array}{c}\text { Країна } \\
\text { власник }\end{array}$ & $\begin{array}{c}\text { Просторове } \\
\text { розрізнення, м }\end{array}$ & $\begin{array}{c}\text { Ширина смуги } \\
\text { знімання, км }\end{array}$ & $\begin{array}{c}\text { Спектральна } \\
\text { характеристика }\end{array}$ & \begin{tabular}{|c|} 
Повторне знімання, \\
діб \\
\end{tabular} \\
\hline 1 & WorldView-1 & США & 0,5 & 17,7 & панхроматичний & 1,7 \\
\hline 2 & WorldView-2 & США & 0,46 & 16,4 & панхром., 8 мультиспектр. & 1,1 \\
\hline 3 & WorldView-3 & США & 0,31 & 13,2 & панхром., 8 мультиспектр. & 1 \\
\hline 4 & GeoEye-1 & США & 0,41 & 15,3 & панхром., 4 мультиспектр. & $<3$ \\
\hline 5 & Pleades-1A & Франція & 0,54 & 20 & панхром., 4 мультиспектр. & 1 \\
\hline 6 & Pleades-1B & Франція & 0,54 & 20 & панхром., 4 мультиспектр. & 1 \\
\hline 7 & Spot-6 & Франція & 1,5 & 60 & панхром., 4 мультиспектр. & 1 \\
\hline 8 & Spot-7 & Франція & 1,5 & 60 & панхром., 4 мультиспектр. & 1 \\
\hline 9 & Kompsat-3 & Півд. Корея & 0,7 & 16 & панхром., 4 мультиспектр. & $<3$ \\
\hline 10 & Kompsat-3A & Півд. Корея & 0,55 & 16 & панхром., 4 мультиспектр. & $<3$ \\
\hline 11 & Eros B & Ізраїль & 0,7 & 7 & панхроматичний & $<3$ \\
\hline 12 & SuperView-1 & KHP & 0,7 & 12,1 & панхром., 4 мультиспектр. & $<3$ \\
\hline
\end{tabular}

3. Обсяг використовуваних оптикоелектронних знімків значно перевищує такий обсяг для радіолокаційних знімків. Основними операторами радіолокаційних апаратів є: Південнокорейська компанія - КА Kompsat-5; Німецька компанія - KA TerraSAR-X та TANDEM-X; Італійська компанія - KA Cosmo-SkyMed-1/2/3/4, Канадська компанія - KA RadarSat-2. Основні технічні характеристики КА Д33 радіолокаційного спостереження високого просторового розрізнення наведені в табл. 3 [8-15].

Таблиця 3

Технічні характеристики космічних апаратів Д33 радіолокаційного спостереження високої просторової розрізненості на місцевості

\begin{tabular}{|c|c|c|c|c|}
\hline № & Космічний апарат & Країна власник & Просторове розрізнення*, м & Розмір сцени, км $^{2}$ \\
\hline 1 & Kompsat-5 & Півд. Корея & 1 & $5 \times 5$ \\
\hline 2 & TerraSAR-X / TANDEM-X & ФРН & 0,25 & $4 \times 3,7$ \\
\hline 3 & Cosmo-SkyMed-1/2/3/4 & Італія & 1 & $10 \times 10$ \\
\hline 4 & RadarSat-2 & Канада & 3 & $10 \times 10$ \\
\hline
\end{tabular}

$(*)$ - зазначене просторове розрізнення у телескопічному режимі знімання. У зазначеному режимі КА має найкраще розрізнення на місцевості.

4. У середньому комерційна вартість матеріалів Д33: оптико-електронного спостереження складає: \$20-30 за км² у разі замовлення нового знімання та \$10-15 за км² для архівних знімків, а радіолокаційного спостереження: $\quad \$ 60-80$ за км ${ }^{2}$ у разі замовлення нового знімання та $\$ 30-40$ за км² для архівних знімків. Загалом вартість матеріалів радіолокаційного космічного знімання одиниці площі поверхні Землі високого просторового розрізнення у 2-3 рази вища ніж вартість аналогічних матеріалів 
оптико-електронного знімання.

Аналіз розвитку техніки та технологій радіолокаційного космічного знімання (табл. 3) дає підстави стверджувати, що просторове розрізнення матеріалів радіолокаційного космічного знімання вже досягло субметрового значення та й надалі невпинно покращуватиметься. Указане обумовлює зростаючий інтерес споживачів до радіолокаційних матеріалів космічного знімання, що спонукає регулярне збільшення кількості запусків КА радіолокаційного спостереження.

Якщо порівняти радіолокаційні та оптико-електронні космічні знімки за інформативністю, то більш інформативними $є$ оптико-електронні, хоча радіолокаційні знімки $є$ суттєвим доповнення до перших. Особливо таке доповнення є критичним у разі поганих метеоумов чи сезонних коливаннях освітленості поверхні Землі.

Якщо розглянути можливі варіанти (сервіси) 3 отримання матеріалів космічного знімання у операторів комерційних КА Д33, то таке отримання на комерційних засадах може здійснюватися у такі способи:

1. Замовлення необхідних матеріалів Д33 із потрібним рівнем оброблення безпосередньо у оператора космічної системи Д33 або у його дистриб'юторів. Як правило, отримання споживачем відзнятих матеріалів здійснюється, через мережу Internet (завантаження за посиланням);

2. Придбання та встановлення власної наземної станції приймання спеціальної інформації Д33, купівля у комерційного оператора ліцензії на приймання матеріалів Д33, замовлення знімання та ліцензійне приймання даних Д3З безпосередньо з борту КА. Однак більшість операторів найбільш інформативних сучасних КА ДЗ3 не передбачають можливість такого продажу;

3. Використання замовником технології “віртуальної приймальної станції, яка передбачає: встановлення замовнику на комерційних засадах спеціального програмного забезпечення, що дає змогу замовляти космічне знімання через мережу Internet, тобто надавати замовнику інформаційний ресурс космічного апарату Д33; приймання даних Д33 будь-якою наземною станцією оператора, яка знаходиться у зоні радіовидимості КА Д33; передавання прийнятих даних ДЗ3 замовнику через мережу Internet у режимі онлайн.

Ціна матеріалів космічного знімання у компанії-дистриб'ютора або оператора космічного апарату суттєво залежить від їх детальності та просторових характеристик. Ціна архівних матеріалів космічного знімання у 1,5-2 рази нижче за матеріали замовленого космічного знімання.

Окремо слід наголосити, що багато у чому, галузь Д33 розвивається спираючись на "Принципи, які стосуються ДЗ3 з космосу", які затверджені у Комітеті ООН з космосу та Генеральній асамблеї ООН (резолюція 41/65 від 3 грудня 1986 р.). Принцип 4 проголошує вільне розповсюдження даних Д3З на міжнародній арені у тій мірі, у якій це не наносить шкоди законним правам та інтересам країни, що зондується. Питання тільки у тому, як власник космічної системи розуміє ці "права та інтереси" [16].

Зважаючи на зазначене, діяльність кожного комерційного оператора космічної системи Д3З високої просторової розрізненості суворо регламентована внутрішнім законодавством країни власника. До того ж, така регламентація може [17]:

повністю виключати розповсюдження матеріалів знімання окремих районів, чи не дозволяти їх продаж деяким країнам;

вводити обмеження на детальність знімків, часовий інтервал між їх отриманням та наданням замовнику (насамперед іноземному) тощо.

Однак достатньо значна кількість операторів космічних систем Д33, їх різне територіальне розташування та політичні уподобання їх країн власників (табл. 1) дають змогу обрати компанію, яка продасть необхідний знімок 3 необхідними характеристиками та 3 обмеженнями, що задовольняють покупця.

3 огляду на викладене, розглянемо українські компанії-дистриб'ютори, які розповсюджують матеріали космічного знімання 3 іноземних комерційних КА, це: Державний науково-виробничий центр “Природа", “ЕСОММ со”, “ТВИС”, CES тощо. Узагальнені відомості щодо вартості матеріалів космічного знімання для зазначених компаній, 3 їх офіційних сайтів, наведено у табл. 4 і табл. 5, де: архівні дані оптико-електронного знімання - дані, 3 моменту отримання яких минуло більше 30 діб (ціна складає 50\% ціни оперативних отриманих даних); архівні дані радіолокаційного знімання - дані, 3 моменту отримання яких минуло більше 90 діб.

Окремо слід наголосити, що за потреби та можливості придбати значні обсяги матеріалів Д33, окремі покупці (організації, 
установи) можуть скористатися варіантом придбання таких матеріалів безпосередньо у оператора космічної системи, без участі фірми посередника. Однак такий варіант потрібно розглядати індивідуально.

Таким чином, першим можливим варіантом отримання даних Д3З високої просторової розрізненості на місцевості $\epsilon$ комерційна закупівля таких матеріалів через компанії-дистриб'ютори операторів космічних систем ДЗЗ.

Таблиця 4

Комерційна вартість матеріалів оптико-електронного космічного знімання високого просторового розрізнення на місцевості

\begin{tabular}{|c|c|c|c|c|c|}
\hline \multirow{2}{*}{ № } & \multirow{2}{*}{$\begin{array}{l}\text { Космічний } \\
\text { апарат }\end{array}$} & \multirow{2}{*}{$\begin{array}{c}\text { Просторове } \\
\text { розрізнення знімку }\end{array}$} & \multicolumn{2}{|c|}{ Замовлення на знімання } & \multirow{2}{*}{$\begin{array}{c}\text { Архівні } \\
\text { дані, за км² }\end{array}$} \\
\hline & & & Мінімальний розмір замовлення & Вартість за км² & \\
\hline 1 & Pleades-1A/B & $0,5-0,7 \mathrm{M}$ & $5 \times 5 \mathrm{KM}^{2}$ & $€ 27$ & $€ 13$ \\
\hline \multirow{2}{*}{2} & \multirow{2}{*}{ WorldView-3 } & $0,3 \mathrm{M}$ & $10 \times 10$ км $^{2}$ & $\$ 84$ & $\$ 40$ \\
\hline & & $0,4-0,5 \mathrm{M}$ & $10 \times 10 \mathrm{Kм}^{2}$ & $\$ 40$ & $\$ 20$ \\
\hline 3 & Kompsat 3/3A & $0,55-0,7 \mathrm{M}$ & $5 \times 5$ км $^{2}$ & $\$ 22$ & $\$ 11$ \\
\hline
\end{tabular}

Комерційна вартість матеріалів радіолокаційного знімання високого просторового розрізнення на місцевості

\begin{tabular}{|c|c|c|c|c|c|}
\hline \multirow{2}{*}{ № } & \multirow{2}{*}{ Космічний апарат } & \multirow{2}{*}{$\begin{array}{c}\text { Просторове } \\
\text { розрізнення знімку }\end{array}$} & \multicolumn{2}{|c|}{ Замовлення на знімання } & \multirow{2}{*}{$\begin{array}{c}\text { Архівні } \\
\text { дані, за км² }\end{array}$} \\
\hline & & & Розмір стандартної сцени & Вартість за км $^{2}$ & \\
\hline \multirow{2}{*}{1} & \multirow{2}{*}{ Cosmo-Skymed } & $1,0 \mathrm{M}$ & $10 \times 10 \mathrm{KM}^{2}$ & $€ 94,5$ & $€ 47^{*}$ \\
\hline & & $1,0 \mathrm{M}$ & $7 \times 7 \mathrm{KM}^{2}$ & $€ 125,5$ & $€ 78$ \\
\hline 2 & RadarSat-2 & $3,0 \mathrm{M}$ & $7 \times 7 \mathrm{KM}^{2}$ & $€ 90$ & $€ 45$ \\
\hline \multirow{2}{*}{3} & TerraSAR-X/ & $0,25 \mathrm{M}$ & $4 \times 3,7 \mathrm{\kappa м}^{2}$ & $€ 450$ & $€ 250$ \\
\hline & TANDEM-X & $1,0 \mathrm{M}$ & $10 \times 5 \mathrm{Kм}^{2}$ & $€ 119$ & $€ 60$ \\
\hline
\end{tabular}

Наступним варіантом отримання даних Д33 в інтересах національної безпеки i оборони, $є$ підписання контрактів на приймання таких матеріалів на наземні приймальні станції в установі Державного космічного агентства України Національному центрі управління та випробувань космічних засобів (НЦУВКЗ).

Так, зважаючи на відсутність національних КА, в НЦУВКЗ налагоджено приймання на власні наземні станції даних Д3З від іноземних КА високого просторового розрізнення (0,5-0,7 м). Це забезпечує високу оперативність отримання даних i 1 ix максимальну надійність і достовірність.

3 огляду на незадовільне висвітлення цього питання в публікаціях, доцільно провести детальний, за хронологією та характеристиками, огляд таких можливостей [18, 19].

$\boldsymbol{K} \boldsymbol{A} \boldsymbol{E R O S}-\boldsymbol{B} . \quad 32014$ р. приймання інформації надвисокої розрізненості $(0,7$ м) з ізраїльського супутника Д33 EROS-В компанії Image Sat International N.V. Для цього було створено та встановлено на вітчизняну наземну приймальну станцію (УНСПІ-8,2) у Центрі прийому i обробки спеціальної інформації та контролю навігаційного поля, що є філією НЦУВКЗ, програмний комплекс, який проводить декодування, розпаковку прийнятого сигналу та отримання космічних знімків EROS-B 3 радіометричною корекцією, корекцією сенсора та системною геометричною корекцією (рівень обробки 1А та/або 1В).

Для KA EROS-B - мінімальний розмір для одиночного знімання $7 \times 7 \quad \mathrm{~km}^{2}$, для площинного знімання - від 2 знімків. Розрізненість отриманих знімків - не гірше 0,7 м (при зйомці в надир) у панхроматичному каналі (PAN). Точність прив'язки отриманих знімків EROS-B - не гірше, ніж 10 м без використання наземних контрольних точок.

KA EROS-B забезпечує можливість знімання з відхиленням від надиру до $45^{\circ}$.

У 2017 р. НЦУВКЗ, $з$ метою досягнення максимальної швидкості виконання заявок, було закуплено спеціальне програмне забезпечення оперативного планування знімань KA EROS-B. Програмне забезпечення дає змогу приймати рішення щодо планування термінових знімань залежно від їх пріоритетності, обирати визначені витки EROS-B на термін до 3 діб, планувати знімання за 2 доби (в окремих випадках за 1 добу), відміняти знімання і вносити зміни до плану знімань за 1 добу.

Такий підхід, дає змогу забезпечити найвищий рівень оперативності виконання заявок, особливо в інтересах сектору безпеки і оборони, а також у разі несприятливих погодних умов, або у разі високої щільності замовлень через перерозподіл заявок на отримання даних ДЗ3 від державних споживачів.

Приймання даних EROS-B проводиться 
з 2016 року, для чого у компанії Image Sat International N.V. щорічно закуповується бортовий pecypc EROS-B. Наприклад, у 2018 році закупівля склала - 7,5 млн грн.

НЦУВКЗ може планувати проведення знімань земної поверхні у Визначеній зоні інтересів (рис. 3) та поза іiі межами (за окремою домовленістю 3 компанією оператором).

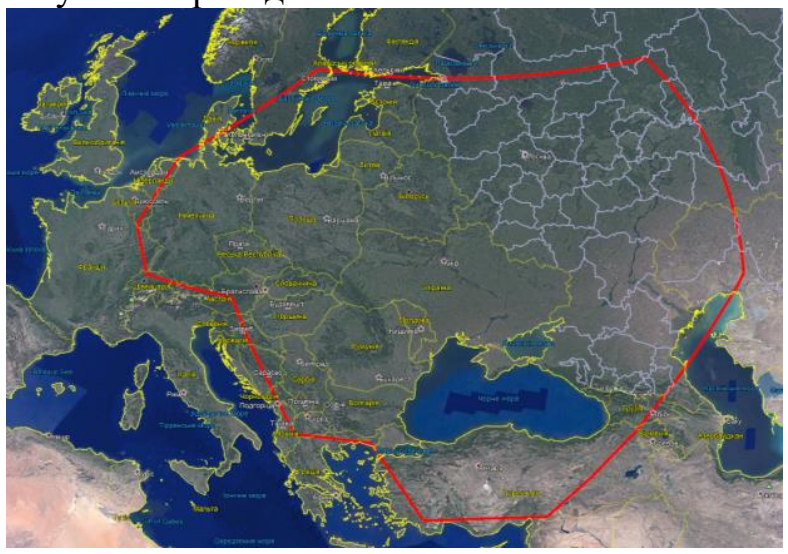

Рис. 3. Визначена зона інтересів

Отримані матеріали Д33, передаються на наземну приймальну станцію УНСПІ-8,2 в $\mathrm{X}$-діапазоні.

Час від отримання замовлення оператором КА до приймання інформації НЦУВК3 від супутника EROS-B на приймальну станцію НЦУВКЗ не більше 1 доби.

У цілому, оперативність виконання заявки на знімання складає:

стандартне замовлення - 1-3 доби (із врахуванням хмарності та точки знаходження КА на момент замовлення);

екстрене замовлення - до 24 годин (без врахування хмарності та за наявності витка над зоною зацікавлення протягом 24 годин).

KA cepiï SuperView-1. У 2018 році, НЦУВКЗ проведено закупівлю у компанії China Great Wall Industry Corporation (CGWIC) бортового ресурсу 4 (чотирьох) супутників типу SuperView-1 (01, 02, 03, 04).

Компанією CGWIC проведено встановлення та випробування на технічних засобах Центру прийому i обробки спеціальної інформації та контролю навігаційного поля (м. Дунаєвці) (чотири сервери) спеціального програмного забезпечення для декодування, розпаковки прийнятого від супутників SuperView-1 (01, $02,03,04)$ сигналу та отримання базового продукту Д3З з радіометричною корекцією, корекцією сенсора та системною геометричною корекцією (рівень обробки 2А).

Супутники серії SuperView-1 (01, 02, 03, 04) виконують площинне знімання - не менше $12 \times 96$ км $^{2}$, точкове знімання $-12 \times 12$ км $^{2}$ та проведення стереознімання (за окремим замовленням). Розрізненість отриманих знімків - 0,5 м (при зніманні в надир) у панхроматичному каналі (PAN) та розрізненістю 2 м (при зніманні в надир) у мультиспектральному діапазоні (MS).

Інформація в мультиспектральному діапазоні надається у чотирьох каналах: зелений $(\mathrm{G})$, червоний $(\mathrm{R})$, синій $(\mathrm{B})$, ближній інфрачервоний (NIR). Точність прив'язки базового продукту ДЗ3 не гірше, ніж 10 м без використання наземних контрольних точок.

Супутники SuperView-1 забезпечують можливість знімання з відхиленням від надиру до $30^{\circ}$. Може бути проведено знімання точкових, площинних об'єктів, а також ведення стереознімання.

Оператор забезпечуе виконання пріоритетних заявок на точкове знімання в період не більше, ніж 48 годин після отримання замовлення. Стандартне планове знімання має проводитись у термін до 30 діб.

Кількість пріоритетних замовлень не може перевищувати $20 \%$ від загальної кількості замовлень. Хмарність має бути не більше $16 \%$.

У цілому, оперативність виконання заявки на знімання складає:

стандартне замовлення - від 72 годин (за сприятливих погодних умов);

пріоритетне замовлення - до 48 годин (вища ціна), екстрене замовлення - до 24 годин (найвища ціна).

У разі пріоритетного i екстреного замовлень за прогноз погодних умов відповідає замовник, тобто знімання і оплата проводиться без урахування хмарності;

Висновки. Таким чином можна зазначити: 
1. На сьогоднішній день світовий ринок ДЗ3 високого просторового розрізнення стійко зростає. Основними споживачами матеріалів Д33 є урядові та силові відомства.

2. Діяльність операторів космічних систем ДЗЗ високої просторової розрізненості суворо регламентована внутрішнім законодавством, що може суттєво ускладнити (унеможливити) закупівлю знімків. Однак достатня кількість операторів, їх різне територіальне розташування та політичні уподобання дають змогу обирати компанію, яка продасть необхідні матеріали.

3. Для вирішення завдань національної безпеки і оборони, найбільш інформативними $\epsilon$ матеріали Д3З оптико-електронного спостереження, до того ж матеріали радіолокаційного космічного знімання $€$ ï суттєвим доповненням. Комерційна вартість оптико-електронних знімків у 3 рази нижча за радіолокаційні.

4. За умов відсутності національних КА Д3З високого просторового розрізнення, у Національному центрі управління та випробувань космічних засобів, за бюджетні кошти, налагоджено приймання на власні наземні станції даних Д3З від іноземних комерційних оптико-електронних супутників надвисокого просторового розрізнення. Це, по-перше, дає змогу якісно використовувати наявну наземну космічну інфраструктуру та, по-друге, забезпечує високу оперативність отримання даних Д33 i ïx максимальну надійність і достовірність.

5. На теперішній час, наземні станції Національного центру управління та випробувань космічних засобів приймають дані від 4 супутників надвисокої розрізненості "SuperView-1" (Китай) - мультиспектральні (кольорові) знімки розрізненістю - 0,5 м і супутника "Eros-B" (Ізраїль) - панхроматичні (чорно-білі) знімки розрізненістю 0,7 м.

Наприкінці 2020 року очікується запуск ще 2 супутників "SuperView-1", що дасть змогу отримувати дані вже не від 4, а від 6 космічних апаратів цього типу. Також, опрацьовується питання отримання у найближчій перспективі радарних супутникових даних 3 надвисокою розрізненістю $(0,5-1 \mathrm{M})$ - це дасть змогу суттєво, а іноді критично, доповнювати дані оптико-електронних супутників.

6. Подальшою перспективою розвитку напряму отримання матеріалів Д3З високої просторової розрізненості вбачається, поряд зі збільшенням пропозицій від українських компаній дистриб'юторів, які розповсюджують матеріали космічного знімання 3 іноземних комерційних КА, поперше, запуск вітчизняних КА ДЗЗ високої просторової розрізненості (на початку оптикоелектронного, a далі радіолокаційного спостереження) та, по-друге, подальше нарощування спроможностей Національного центру управління та випробувань космічних засобів щодо закупівлі послуг у іноземних комерційних компаній власників космічних систем ДЗЗ.

Такий підхід $\epsilon$ перспективним для максимальної ефективності отримання даних Д3З високої просторової розрізненості в інтересах національної безпеки і оборони.

\section{СПИСОК ВИКОРИСТАНОЇ ЛІТЕРАТУРИ}

1. Про космічну діяльність : Закон України від 15.11.1996 p. № 502/96-BP-VII (зі змінами).

2. Про схвалення Концепції реалізації державної політики у сфері космічної діяльності на період до 2032 року : розпорядження Кабінету Міністрів України від 30.03.2011 p. № 238-p.

3. Про затвердження плану заходів щодо виконання Концепції реалізації державної політики у сфері космічної діяльності на період до 2032 року : розпорядження Кабінету Міністрів України від 25.01.2012 p. № 48-p.

4. Про рішення Ради національної безпеки $\mathrm{i}$ оборони України від 11 листопада 2015 року "Про забезпечення видовою інформацією державних органів" : Указ Президента України від 01.12.2015 р. № 673/2015.

5. Офіційний сайт. URL: http://www.euroconsultес.com/ (дата звернення 25.12.2019).

6. Офіційний сайт. URL: http://www.SpaceNews.com/ (дата звернення 10.12.19).

7. Офіційний сайт. URL: http://www.MordorIntelligence.com/ (дата звернення 10.01.2020).

8. Офіційний сайт. URL: http://www.space.skyrocket.de/index.html/ (дата звернення 15.12.2019).

9. Офіційний сайт. URL: http://www.lk.astronautilus.pl/index.html/ (дата звернення 20.01.2020).

10. Офіційний сайт. URL: http:// www.spacetrack.org/ (дата звернення 10.02.2020).

11. Офіційний сайт. URL: http://www.celestrak.com/ satcat/boxscore.asp/ (дата звернення 14.02.2020).

12. Офіційний сайт. URL: http://www.spaceflightnow.com/launch-schedule/ (дата звернення 10.12.2019).

13. Офіційний сайт. URL: http://www.nasaspaceflight.com/ (дата звернення 23.12.2019).

14. Космічні апарати знімання поверхні Землі : довідник / за ред. В. В. Омельчука. Київ, 2017. $244 \mathrm{c}$.

15. Випорханюк Д. М., Ковбасюк С. В. Основи 
космічної ситуаційної обізнаності. Житомир, 2018. $532 \mathrm{c}$.

16. Чуларис В. Национальная политика США в области использования космического пространства. Зарубежное военное обозрение. 2007. № 1 .

17. Аналитический обзор космических программ Д33 России и зарубежных стран.
Геоинформационное агентство "Иннотер". Москва, 2013. 108 с.

18. Офіційний сайт. URL: http://www.nkau.gov.ua/ (дата звернення 21.02.2020).

19. Офіційний сайт. URL: http://www.spacecenter.gov.ua/ (дата звернення 19.02.2020).

Стаття надійшла до редакційної колегії 27.11.2020

\section{Analysis of the field of remote sensing of the Earth of high spatial resolution to solve problems in the field of security and defense}

\section{Annotation}

The article analyzes the field of remote sensing of the Earth of high spatial resolution from space and presents the main trends in this field. It is shown that the main consumers of remote sensing materials are government and law enforcement agencies (the share of the latter is about $60 \%$ ).

The main companies of commercial space systems for remote sensing of the Earth of high spatial resolution and companies-distributors (operators) of these systems representing their interests in the Ukrainian market are given. These companies provide information for security and defense tasks and provide pricing policies for remote sensing services. The materials of optoelectronic and radar surveying are considered and the possibilities of the State Space Agency of Ukraine of the National Center for Control and Testing of Spacecraft to obtain space survey materials of high spatial resolution are reviewed.

Described projects for the reception of special information of high spatial diversity, namely:

with the Israeli company Image Sat International N.V. (spacecraft "EROS-B") (panchromatic images with a spatial resolution of $0.7 \mathrm{~m}$ );

with the Chinese company China Great Wall Industry Corporation four spacecraft series "SuperView-1" (multispectral images with a spatial resolution of $0.5 \mathrm{~m}$ ).

The possibilities of receiving and processing materials of remote sensing of the Earth from the specified spacecraft are resulted.

Keywords: remote sensing of the Earth; satellite imagery materials of high spatial resolution; reception of satellite imagery materials; State Space Agency of Ukraine. 